\title{
THE EFFECT OF TEACHING TECHNIQUES AND LEARNING MOTIVATION ON ARGUMENTATIVE ACHIEVEMENT OF GRADE XI STUDENTS.
}

\author{
Albert Pauli Sirait \\ Surel: albertpaulis@gmail.com
}

\begin{abstract}
ABSTRAK
Tujuan penelitian ini adalah untuk mengetahui apakah Prestasi Tulisan Argumentatif siswa yang diajarkan oleh Consultancy Prewriting Protocol Technique (CPPT) secara signifikan lebih tinggi daripada yang diajarkan oleh Word Wall Technique (WWT). Penelitian eksperimen dengan disain faktorial 2x2. 120 siswa kelas XI SMK Negeri 11 Medan sebagai sampel. Motivasi belajar diukur dengan kuesioner. Prestasi tulisan Argumentatif diukur berdasarkan struktur umun tulisan Argumentatif. Data dianalisis menggunakan ANOVA dua arah. (1) prestasi siswa yang diajarkan oleh CPPT $(x=77,95)$ lebih tinggi daripada yang diajarkan oleh WWT $(\mathrm{x}=72,85)$ dengan $\mathrm{F}_{\text {hitung }}=$ $73,8>\mathrm{F}_{\text {tabel }}=3,92$. (2) prestasi siswa dengan motivasi belajar tinggi $(\mathrm{x}=83,5)$ lebih tinggi daripada motivasi belajar rendah $(x=66,95)$ dengan $F_{\text {hitung }}=6,72>$ $\mathrm{F}_{\text {tabel }}=3,92$. (3) terdapat interaksi yang signifikan antara teknik mengajar dan motivasi belajar dengan $F_{\text {hitung }}=28,4<F_{\text {table }}=3,92$.
\end{abstract}

Kata Kunci: Argumentatif, Motivasi Belajar, Teknik Pengajaran.

\section{INTRODUCTION}

The teaching of English has become increasingly important as a foreign or second languages in almost all levels of education. It is the first foreign language taught in Indonesia. It is a compulsory subject to be taught in state or public schools, i.e. Six years in Primary School, three years at Junior High School and three years in Senior High School. Ironically, there are still very limited numbers of students who are able to communicate in simple English, although they have been studying English for about twelve years. The problems that Indonesian EFL learners face in developing their speaking performance are related not only to their linguistic and personality factors, but also the types of classroom tasks provided by the teachers and the teachers' tecnique of teaching.

There are many teachers in Indonesia, especially in Medan who do not apply a good technique in teaching writing. As a consequence, the students are getting confused and bored and no longer well-motivated to study. And of course, it influences the students' achievement in argumentative writing. The data which are obtained from the State Vocational High School (Sekolah Menengah Kejuruan: SMK) 11 Medan show that the students' achievement in writing skills, i.e. expressing meaning in written short functional text and simple essay in the form of Argumentative writing in 

the context of personal experience are low. One of the most important things to consider in solving this problem is by applying Consultancy Prewriting Protocol Technique (CPPT). According to Urquahart \& McIver (2005) a CPPT is a structured process for helping a presenter thinks more expansively about a dilemma. Consultancy prewriting protocols provide a structured way for students to contribute their thoughts and ideas while creating the opportunity to listen to multiple voices. Consultancy prewriting protocols also serve as useful tools to temper dominant voices. Therefore, CPPT has a significant effect to teaching language to students by which the students are freely to contribute their thoughts and ideas through the writing process, because by using it the teacher provides a structured way for helping students to do the writing.

Word Wall Technique (WWT) is a list of the words that the students have encountered in their reading and that can be used in their writing (Linse, 2005). These lists of word can be posted on the walls in the classroom. Learners can refer to a word wall during various stages of the writing process. A word wall is a systematically organized collection of words displayed in large letters on a wall or other large display places in the classroom.

In teaching English, especially in teaching writing, the techniques of teaching are not only needed but also the learning motivation. Learning motivation is the activation of goal-orientated behavior. Students are at their most creative when they feel motivated primarily by interest, satisfacton and challenge of the work itself and not by external pressure or incentives.

Based on the relationships mention above, it can be predicted that student's argumentative writing achievement that are taught by using consultancy prewriting protocol technique is higher than that of the student who are taught by using word wall technique and learning motivation will significantly affect the students' achievement in argumentative writing. To find out whether or not this prediction is true and one of the reasons of researcher in this research interested in knowing the effect of CPPT, WWT and learning motivation on students' achievement in argumentative writing.

The Problem of the Study

Based on the background above the problems are formulated as follows.

- Are the students' argumentative writing achievement taught by using CPPT is higher than that of the students taught by using WWT?

- Are the students' achievement in argumentative writing that has high learning motivation higher than those with low learning motivation? 
- is there any significant interaction between CPPT, WWT, and learning motivation on students' argumentative writing achievement?

\section{RESEARCH METHODOLOGY}

\section{Research Design}

This research was conducted by applying a Factorial Design 2x2. The reasons for choosing this design was; to prove the hypotheses in one experiment, and to recognize the interaction between the dependent and indepedent variables. There are three variables in this study, they were: Independent variables; CCPT and WWT, moderator variable; high and low motivation of learning and dependent variable: students' achievement in argumentative writing. The study compare CPPT, WWT and students' learning motivation.

There were two groups of students in this research namely Group I that had been taught by using CPPT and Group II had been taught by using WWT.

The population of this research was all the Grade XI Students of 2012/2013 academic year of SMK 11 Medan situated on Jalan. Perintis Kemerdekaan Medan. There are four classes of them. Each class consists of 42 students, so the total numbers of the students are 168 students.

The sample was limited by using Slovin's formula. The reason for choosing this formula was to got the representative data and because the population obtained less than 500 people (Sevilla, Consuelo G. et. al (2007). The Slovin's formula is shows as follows.

$$
n=\frac{N}{1+N e^{2}}
$$

Where:

$n$ = sample size

$N=$ margin size

$e=$ error tollerance with confidence level $95 \%(0.05)$

Based on the computation by using Slovin's formula, there were 120 students that was became a sample in this study. To take the sample the cluster random sampling was applied. They were divided into Group I and Group II. This experimental method dealt with two groups; an experimental group and a control group. The first group consisted of 60 students were given treatment by CPPT and the second groups consisted of 60 students were given the treatment by using WWT.

An instrument is very useful in a research because it is used as facilitation in the research by the researcher. In this study there were two kinds of data, they were students' learning motivation which had been collected by using questionnaires and students' argumentative writing achievement by giving a test. This study used a questionnare as an instrument to measure the students' learning motivation. By using this instrument, the students were classified into two groups; high learning motivation and 
the low learning motivation. To measure the students' learning motivation, this questionare were transferred into score based on Likert Scale. This Likert Type presents a number of positive statements regarding an attitude. Each statement consist of five options from the highest statement to the lowest statement and each option was proven score; 1 score for option a, 2 score for option b, 3 score for option c, 4 score for option d, and 5 score for option e.

In evaluating the students' work, analytic scoring rubric from Heaton (1990) was used and the components of writing were scored separately based on scoring purpose of such as content, language use, and mechanic as indicator of analytic method.

The maximum Score is 100 and the minimum is 5. Thus, to identify the final score of the students' achievement in argumentative writing, the following formula is applied:

$$
\text { Score }=\frac{\text { obtained score }}{100} \times 100 \%
$$

The final score was the score obtained by the student based on the scoring components for evaluating the students' writing product, divided by the maximum score and multiplied with $100 \%$. These are the score ranges between $\quad 0-100$ which is used to compare the students' score with the Minimum of Mastery Criteria (MMC).
In this research, the validity of questionaire was used construct validity, because it was used to assess individualization on certain psycological traits and abilities. The validity coefficient of students' learning motivation was computed by employing the Pearson Product Moment formula. The questionnaire will be valid if the validity coefficient $r$ Observed $>r_{\text {Table }}$.

The validity of the writing test used content validity. Content validity refers to the extent to which the instrument represents the content of the interest. In order to have the content validity, a measurer must adequately sample both the topic and the cognitive processes included in the content universe under the consideration.

Based on the computation by using Cronchbach Alpha formula, it was found that the reliability of the questionnaire is 0,805 . It was reliable with the rule of Cronchbach Alpha while Cronchbach Alpha > 0,600. Thus it was indicated that the test items of the questionnaire were valid and realible and then could be administered as one of the instruments in this study to investigate the students' learning motivation.

To measure a test, it needs measuring the instrument and the instrument should be reliable.

The test of reliability of writing test was $r_{\text {computed }}$ is 0.891 . Thus, the test had high reliability then could be administered as one of 
the instrument to collect the data in this study.

One technique to assess students' writing test is using Analytical score. Richards (2004) stated that analytical score is one of rubic scores to assess students' scoring writing performance test clearly defines the features to be assessed by separating the components of the texts namely; content, vocabulary, grammar, organization and mechanic. It is very useful as a diagnostic tool to help the teacher in giving feedback of the weakness and the

\section{Procedures of Treatment}

Before the treatement was conducted, the similarities that influence the teaching and learning activities of both experimental groups were observed first. The purpose of its observation was to ensure that both classes suppose have the same characteristics. The students have a same length of time for the treatement that is $2 \times 45$ minutes. The treatement had conducted in eight meeting in six weeks. The testy was given twice: the first test was questionnaire of learning motivation that was administered before the treatement begins. The second was writing test that is administered after the treatement. It was administered to provide statistical evidence for the effect of the experiment on students' argumentative writing.

The treatment was conducted in both of experimental classes by different teachers. The writer trained the teacher to teach argumentative writing by applying CPPT and the writer taught argumentative writing by applying WWT. In teaching procedure, the teaching learning processes were divided into three steps; namely: pre activity, core activity, and post activity.

\section{Technique of Data Analysis}

In analyzing the data, the researcher used a two way ANOVA' $2 \times 2$ Factorial Design of the level of significant $5 \%$ or $\alpha=0.05$. This means to prove whether the two techniques CPPT and WWT were significantly effective on students' achievement in argumentative writing and later to discover which techniques more significantly effective.

There are two requirements for analysis before ANOVA is done, namely normality and homogeneity. Normality test was used Liliefors test and homogenity test was used F-test and Barlett Test. If there are interaction between both independent variable toward dependent variable from the result of the F-observed analysis, so the next analysis used Tuckey-test because the numbers of the research sample of each cell in research design are same.

\section{Data Analysis and Research Findings}

The data of the students' writing argumentative achievement from every interaction between Consultancy Prewriting Protocol 
Technique (CPPT), Word Wall Technique (WWT), and students' learning motivation which obtained the maximum and minimum scores, mean, standard deviation, and variance. The summary of the research data analysis can be observed in this Table.

Table Summary of Data Analysis

\begin{tabular}{|c|c|c|c|c|c|c|c|c|}
\hline $\begin{array}{c}\text { Stat. } \\
\text { Values }\end{array}$ & $\mathbf{A 1}$ & $\mathbf{A 2}$ & $\mathbf{B 1}$ & $\mathbf{B 2}$ & $\begin{array}{c}\mathbf{A 1 B} \\
\mathbf{1}\end{array}$ & $\begin{array}{c}\mathbf{A 1 B} \\
\mathbf{2}\end{array}$ & $\begin{array}{c}\mathbf{A 2 B} \\
\mathbf{1}\end{array}$ & $\begin{array}{c}\mathbf{A 2 B} \\
\mathbf{2}\end{array}$ \\
\hline $\mathrm{N}$ & 60 & 60 & 60 & 60 & 30 & 30 & 30 & 30 \\
\hline Max. & 96 & 85 & 96 & 80 & 96 & 80 & 85 & 80 \\
\hline Min. & 50 & 50 & 70 & 50 & 73 & 50 & 70 & 50 \\
\hline Mean & 77.7 & 73.5 & 83.4 & 66.8 & 88.2 & 66 & 77.9 & 67.4 \\
\hline Median & 83.1 & 73.5 & 84.5 & 76.5 & 89.5 & 72.1 & 80.2 & 70.4 \\
\hline Mode & 94.2 & 82 & 84.5 & 66 & 94,9 & 65.3 & 80.7 & 78.1 \\
\hline Std Dev & 13.5 & 9.12 & 9.12 & 8.80 & 14.3 & 8.81 & 5.39 & 8.21 \\
\hline Var. & 183 & 83.3 & 83.3 & 77.4 & 204 & 77.7 & 29.6 & 67.5 \\
\hline
\end{tabular}

In Table summary of Data Analysis indicates that the highest score in Argumentative writing of the students taught by using CPPT is 96 and the lowest score is 50. From the calculation it is indicates that the mean score is 77.78 , the median is 83.1, the mode is 94.26 and the standard deviation 13.54. Frequency distribution of the score of the students taught by using CPPT are described in Table as follows.

Table Frequency Distribution of the Score of the Students who Taught by CPPT

\begin{tabular}{|c|c|c|c|}
\hline Class & Interval & $\begin{array}{c}\text { Absolute } \\
\text { Frequency }\end{array}$ & $\begin{array}{c}\text { Relative } \\
\text { Frequency } \\
(\%)\end{array}$ \\
\hline 1 & $50-55$ & 3 & 5 \\
\hline 2 & $56-61$ & 7 & 11.66 \\
\hline 3 & $62-67$ & 4 & 6.67 \\
\hline 4 & $68-73$ & 10 & 16.66 \\
\hline 5 & $74-79$ & 3 & 5 \\
\hline 6 & $80-85$ & 15 & 25 \\
\hline 7 & $86-91$ & 2 & 3.33 \\
\hline 8 & $92-97$ & 16 & 36.67 \\
\hline \multicolumn{2}{|c|}{ Total } & 60 & 100 \\
\hline
\end{tabular}

In Table above, indicates that the average score of students taught by using CPPT is in interval 74-79 with the number of students is 3 or 5 $\%$. The students who got the scores below the average score is 24 students or $40 \%$ and 33 students or $55 \%$ got scores above the average score. A clear description of the score distribution on the students taught by using CPPT can be seen in Figure as bellow.

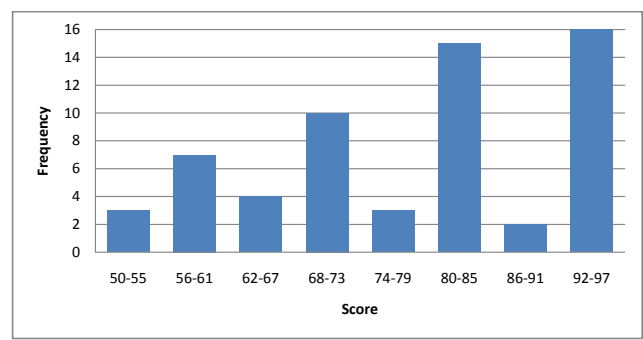

Figure Histogram of Scor distribution.

Table above indicates that the highest score in Argumentative writing of students taught by using Word Wall Technique is 85 and the lowest is 50. The calculation indicates that the mean score is 72.9 , the median is 73.5 , the mode is 82 , the standard deviation is 9.12 and the variance is 83.34. The scores distribution of the students taught by using WWT are described in this Table.

Table Frequency Distribution of the Students' Score Taught by WWT

\begin{tabular}{|c|c|c|c|}
\hline Class & Interval & $\begin{array}{c}\text { Absolute } \\
\text { Frequency }\end{array}$ & $\begin{array}{c}\text { Relative } \\
\text { Frequency } \\
(\%)\end{array}$ \\
\hline 1 & $50-55$ & 2 & 3.33 \\
\hline 2 & $56-61$ & 8 & 13.3 \\
\hline 3 & $62-67$ & 6 & 10 \\
\hline 4 & $68-73$ & 14 & 23.33 \\
\hline 5 & $74-79$ & 6 & 10 \\
\hline 6 & $80-85$ & 24 & 40 \\
\hline \multicolumn{2}{|c|}{ Total } & 60 & 100 \\
\hline
\end{tabular}


Table above shows that the average scores of the students taught by using Word Wall Technique are in interval 68-73 with 14 students or $23.33 \%$. The students who got below the average are 16 students or $26.6 \%$ and 30 students or $50 \%$ got the scores above the average scores. A clear description of the scores distribution on students taught by using WWT can be seen in below Figure.

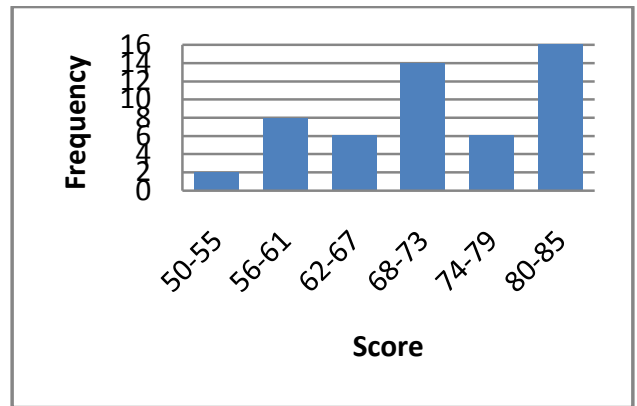

Figure Histogram of Students' Argumentative Writing Achievement taught by using Word Wall Technique

The achievement of students in Argumentative writing with high learning motivation indicates that the highest score is 98 and the lowest score is 70 . The calculation indicates that the mean score is 84,1 , the median is 84,09 , the mode is 87,85 , the standard deviation is 8,63 , and the variance is 74,56 . The scores distribution of the students with high learning motivation are described in this table.
Table Frequency Distribution of the Score of the Students with High Learning Motivation

\begin{tabular}{|c|c|c|c|}
\hline Class & Interval & $\begin{array}{c}\text { Absolute } \\
\text { Frequency }\end{array}$ & $\begin{array}{c}\text { Relative } \\
\text { Frequency }\end{array}$ \\
\hline 1 & $70-75$ & 11 & 18.33 \\
\hline 2 & $76-81$ & 15 & 25 \\
\hline 3 & $82-87$ & 16 & 26.67 \\
\hline 4 & $88-93$ & 4 & 6.67 \\
\hline 5 & $94-97$ & 14 & 23.33 \\
\hline \multicolumn{2}{|c|}{ Total } & 60 & 100 \\
\hline
\end{tabular}

Table above indicates that the average score of students in writing argumentative with high learning motivation is interval $82-87$ with the number of students is 16 or $26.67 \%$. The students who got score below the average score are 27 or $45 \%$ and 18 students or $30 \%$ got scores above the average score. The clear description of the scores distribution of students with high learning motivation can be seen in figure below.

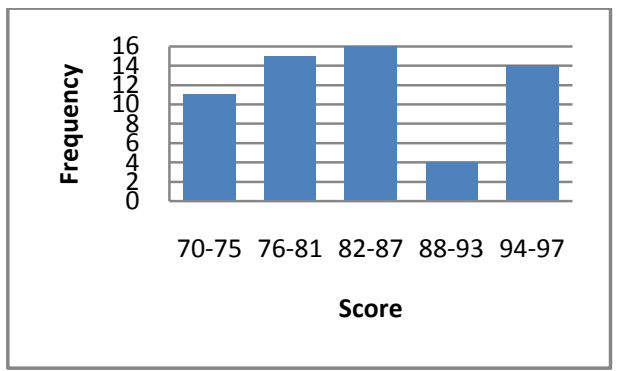

Figure Histogram of Argumentative Writing Achievement of Students with High Learning Motivation

The achievement of students in writing argumentative with low learning motivation indicates that the highest score is 80 and the lowest score is 50 . The calculation indicates 
that the mean score is 66.8 , the median is 71.6 , the mode is 70.25 , the standard deviation is 8.80 and the variance is 77.45. The scores distribution of the students with low learning motivation are described in this Table.

Table Frequency Distribution of the Students' Score with Low Learning Motivation

\begin{tabular}{|c|c|c|c|}
\hline Class & Interval & $\begin{array}{c}\text { Absolute } \\
\text { Frequency }\end{array}$ & $\begin{array}{c}\text { Relative } \\
\text { Frequency }\end{array}$ \\
\hline 1 & $50-54$ & 5 & 8.33 \\
\hline 2 & $55-59$ & 1 & 1.66 \\
\hline 3 & $60-64$ & 16 & 26.66 \\
\hline 4 & $65-69$ & 19 & 31.66 \\
\hline 5 & $70-74$ & 3 & 5 \\
\hline 6 & $75-79$ & 3 & 5 \\
\hline 7. & $80-84$ & 13 & 21.6 \\
\hline \multicolumn{2}{|c|}{ Total } & 60 & 100 \\
\hline
\end{tabular}

Table above indicates that the mean score of students in writing argumentative with low learning motivation is in interval 65-69 with the number of students is 19 or 31,66 $\%$. The students who got the score below the average score are 22 students or $36.66 \%$ and 19 students or $31.66 \%$ got scores above the average score. The clear description of the students with low learning motivation can be seen in this figure.

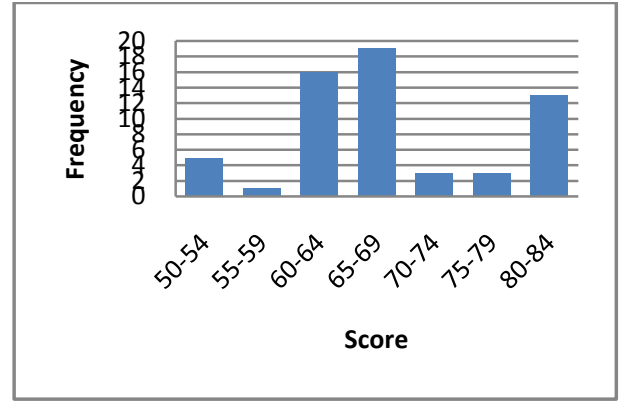

Figure Histogram of Argumentative writing achievement of Students with Low Learning Motivation.
Figure above displays that there are 5 students who got score of Argumentative writing in interval 5054 , there are 1 student who got score in interval 55-59, there are 16 students who got score in interval 6569 , there are 3 students who got score in interval 70-74, there are 3 students who got score in interval 7579 , and there are 13 students who got score in interval 80-84.

The achievement in Argumentative writing of student with high learning motivation taught by using CPPT indicates that the highest score is 96 and the lowest score is 73 . The calculation indicates that the mean score is 88.23 , the median is 89.5 , the mode is 94.9 , the standard deviation is 14.3 , and the variance is 204.9. The scores distribution of the students with high learning motivation taught by CPPT are described in Table as follows.

Table Frequency Distribution of the Score of the student with High Learning Motivation taught by CPPT

\begin{tabular}{|c|c|c|c|}
\hline Class & Interval & $\begin{array}{l}\text { Absolute } \\
\text { Frequency }\end{array}$ & $\begin{array}{c}\text { Relative } \\
\text { Frequency } \\
(\%)\end{array}$ \\
\hline 1 & $73-77$ & 2 & 6.66 \\
\hline 2 & $78-82$ & 2 & 6.66 \\
\hline 3 & $83-87$ & 9 & 30 \\
\hline 4 & $88-92$ & 1 & 1.66 \\
\hline 5 & 93-97 & 16 & 53.33 \\
\hline \multicolumn{2}{|c|}{ Total } & 30 & 100 \\
\hline
\end{tabular}

Table above shows that the average score of students with high learning motivation taught by using Consultancy Prewriting Protocol Technique is in interval 83-87 with 
the number of students is 9 or $30 \%$. The students who got the scores below the average score are 4 students or $13.33 \%$ and 17 students or $56.67 \%$ got scores above the average score. The score distribution of the students with high learning motivation taught by using Consultancy Prewriting Protocol Technique can be seen in Figure as follows.

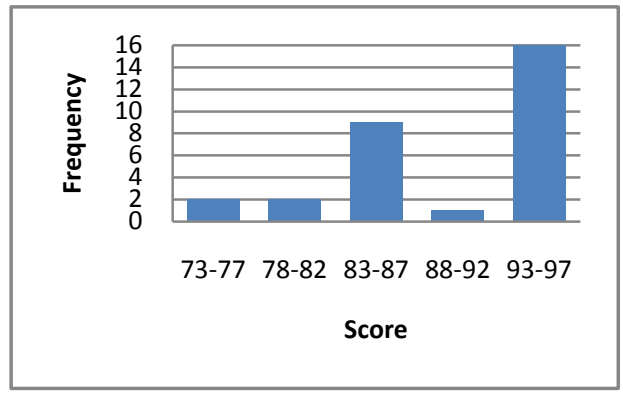

Figure Histogram of Argumentative Writing Achievement of Students with High Learning Motivation taught by CPPT

Figure 5 displays that there are 2 student who got score or Argumentative writing in interval 7377 , there are 2 students who got score in interval 78-82, there are 9 students who got score in interval 8387 , there are 1 student who got score in interval 88-92, and there are 16 students who got score in interval 9397.

The achievement in Argumentative writing of the students' with low learning motivation taught by CPPT indicates that the highest score is 80 and the lowest score is 50 . The calculation indicates that the mean score is 65.36 the median is 67.75 , the mode is
77.5, the standard deviation is 8.19 and the variance is 67.1. The score distribution of the students with low learning motivation taught by CPPT are shown in Table as follows.

\section{Table Frequency Distribution of the score of the Students with Low Learning Motivation who taught by CPPT}

\begin{tabular}{|c|c|c|c|}
\hline Class & Interval & $\begin{array}{c}\text { Absolute } \\
\text { Frequency }\end{array}$ & $\begin{array}{c}\text { Relative } \\
\text { Frequency }\end{array}$ \\
\hline 1 & $50-55$ & 3 & 10 \\
\hline 2 & $56-61$ & 7 & 23.33 \\
\hline 3 & $62-67$ & 4 & 13.33 \\
\hline 4 & $68-73$ & 8 & 26.66 \\
\hline 5 & $75-80$ & 8 & 26.66 \\
\hline \multicolumn{2}{|c|}{ Total } & 30 & 100 \\
\hline
\end{tabular}

Table above indicates that the average score of students with low learning motivation taught by CPPT is in interval 62-67 with the number of the students are 4 or $13.33 \%$. The students who got the scores below the average score are 10 students or $16.66 \%$ and 16 students or $53.33 \%$ got score above the average score. The clear description of the scores distribution on low learning motivation students taught by CPPT can be seen in Figure as follows:

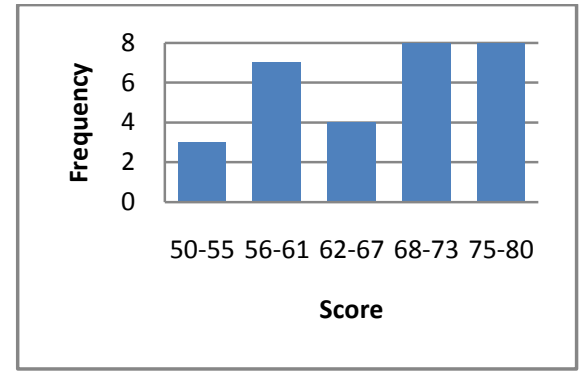

Figure Histogram of Argumentative Writing Achievement of Students with Low Learning Motivation Taught by CPPT 
Figure above shows that there are 3 students who got score of Argumentative writing in interval 5055 , there are 7 students who got score in interval 56-61, there are 4 students who got score in interval 62-67, there are 8 students who got score in interval 68-73, and there are 8 students who got score 75-80.

The achievement in Argumentative writing of the students with high learning motivation taught by using WWT indicates that the higest score is 85 and the lowest score is 70 . The calculation indicates that the mean score is 77.97 , the median is 80.2 , the mode is 80.7, the standard deviation is 5.39 and the variance is 29.06. The scores distribution of the students with high learning motivation taught by using WWT are presented in Table as follows:

Table Frequency Distribution of the Score of the students with High Learning Motivation Taught by WWT

\begin{tabular}{|c|c|c|c|}
\hline Class & Interval & Absolute Frequency & Relative Frequency \\
\hline 1 & $70-73$ & 8 & 26.66 \\
\hline 2 & $74-77$ & 3 & 10 \\
\hline 3 & $78-81$ & 11 & 36.66 \\
\hline 4 & $82-85$ & 8 & 26.66 \\
\hline \multicolumn{2}{|c|}{ Total } & 30 & 100 \\
\hline
\end{tabular}

Table above indicates that the average scores of the students with high learning motivation taught by using WWT are in interval 78-81 with the number of students 11 students or $36,66 \%$. The students who got below the average are 11 students or $36.66 \%$ and 11 students or $26.66 \%$ got the scores above the average scores.

The clear description of the score distribution of students with high learning motivation taught by using Word Wall Technique can be seen in figure as follows.

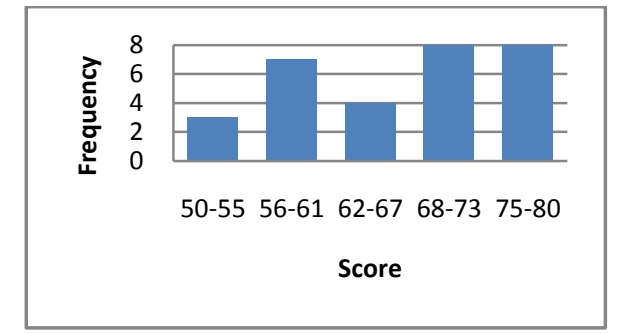

Figure Histogram of Argumentative Achievement of Student with High Learning Motivation taught by using WWT

Figure 7 displays that there are 3 students who got score of Argumentative writing in interval 5055 , there are 7 students who got score in interval 56-61, there are 4 students who got score in interval 6267, there are 8 students who got score in interval 68-73, and there are 8 students who got score in interval 75-80.

The achievement in Argumentative writing of the students with low learning motivation taught by using WWT indicates that the highest score is 80 and the lowest score is 50. The calculation indicates that the mean score is 67.46 , the median is 70.48 , the mode is 78.14 , the standard deviation is 2.59 and the variance is 6.75. The scores distribution of the students with low learning motivation taught by using Word 
Wall Technique are described in Table as follows:

Table Frequency Distribution of the Score of the Students with Low Learning Motivation Taught by using WWT

\begin{tabular}{|c|c|c|c|}
\hline Class & Interval & $\begin{array}{l}\text { Absolute } \\
\text { Frequency }\end{array}$ & $\begin{array}{l}\text { Relative } \\
\text { Frequency }\end{array}$ \\
\hline 1 & $50-55$ & 2 & 6.66 \\
\hline 2 & $56-60$ & 8 & 26.67 \\
\hline 3 & $61-65$ & 6 & 20 \\
\hline 4 & $66-70$ & 6 & 20 \\
\hline 5 & $71-75$ & - & 0 \\
\hline 6 & $78-80$ & 8 & 26.67 \\
\hline \multicolumn{2}{|c|}{ Total } & 30 & 100 \\
\hline
\end{tabular}

Table above presents the average scores of the students with low learning motivation taught by WWT are in interval 66-70 with the number of the students is 6 or $20 \%$. The students who got below the average are 16 students or $53,33 \%$ and 8 students or $20 \%$ above the average.

The Clear description of the scores distribution on students with low learning motivation taught by WWT can be seen in Figure as follows.

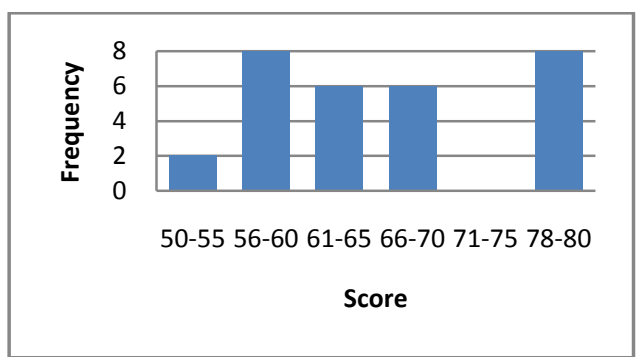

Figure Histogram of Argumentative Writing Achievementof Students with Low Learning Motivation taught by WWT.
Figure 8 shows that there are 2 students who got score of Argumentative writing in interval 5055 , there are 8 students who got score in interval 56-60, there are 6 students who got score in interval 6165 , there are 6 students who got score in interval 66-70, and there are 8 students who got score in interval 78-80.

\section{Requirements of Data Analysis}

Before the research data were analyzed by using two-way analysis of Variance (ANOVA) normality and homogeneity of the data were tested.

\section{Normality Test}

The normality test aims to display that the sample data of the study is normality distributed, the technique used was Liliefors-test on $\alpha=0.05$ significance level. Based on the calculation result, the data obtained from each group is shown in Table as follows.

Table Summary of the Result of Normality Test

\begin{tabular}{|c|c|c|c|c|}
\hline Samples & $\mathrm{N}$ & $\mathrm{L}_{\text {Observed }}$ & $\mathrm{L}_{\text {Table }}$ & Descript \\
\hline A1 & 60 & 0.0690 & 0.140 & \multirow{8}{*}{ Normal } \\
\hline A2 & 60 & 0.1088 & 0.140 & \\
\hline $\bar{B} 1$ & 60 & 0.0801 & 0.140 & \\
\hline B2 & 60 & 0.0587 & 0.140 & \\
\hline A1B1 & 30 & 0.1443 & 0.161 & \\
\hline A1B2 & 30 & 0.1178 & 0.161 & \\
\hline A2B1 & 30 & 0.0702 & 0.161 & \\
\hline A2B2 & 30 & 0.0993 & 0.161 & \\
\hline
\end{tabular}

Table above displays $\mathrm{L}_{\text {Observed }}$ values of each group are lower than $\mathrm{L}_{\text {Table. }}$ It can be conclude that the scores of the students' argumentative 
writing achievement for each group are normally distributed. After the normality of the data had been calculated, the further stage in requirements of analysis of variance was homogeneity test.

\section{Homogeneity Test}

The homogeneity test aims to investigating whether the variance of the data is homogeneous. The test criterion $\mathrm{F}_{\text {Observed }} \leq \mathrm{F}_{\text {Table }}$ indicated that population is homogenous. In this study, homogeneity test was to compare variance of data on students' achievement in writing argumentative between CPPT and WWT. It was also to compute between high and low learning motivation. Homogeneity test of variance was calculated by using Ftest for teaching techniques and learning motivation and the Interaction of the groups was calculated by using Barlett test.

\section{Groups of Teaching Techniques}

The results of the computation of homogeneity of teaching techniques can be observed in Table above.

Table The Result of Homogeneity Test of Teaching Techniques

\begin{tabular}{|c|c|c|c|c|}
\hline $\begin{array}{c}\text { Sampl } \\
\text { es }\end{array}$ & S1 $^{2}$ & $\begin{array}{c}\mathrm{F}_{\text {Observ }} \\
\text { ed }\end{array}$ & $\begin{array}{c}\mathrm{F}_{\text {Tabl }} \\
\mathrm{e}\end{array}$ & Description \\
\cline { 1 - 3 } $\mathrm{A} 1$ & $\begin{array}{c}13.5 \\
4\end{array}$ & 1.48 & 1.56 & $\begin{array}{c}\text { Homogeneo } \\
\text { us }\end{array}$ \\
\cline { 1 - 2 } $\mathrm{A} 2$ & 9.12 & & & \\
\hline
\end{tabular}

Table above reveals that $\mathrm{F}_{\text {Observed }}=1.48$ from group of $\mathrm{CPPT}$ and WWT are lower than $\mathrm{F}_{\text {Table }}=$ 1,56. Thus it can be concluded that the population of each teaching techniques group is homogenous.

\section{Groups of Learning Motivation}

The result of calculation on group of learning motivation is shown in Table below.

\section{Table The Results of Homogeneity} Test of Learning Motivation

\begin{tabular}{|c|c|c|c|c|}
\hline Sample & $\mathrm{S}^{2}$ & $\mathrm{~F}_{\text {Obs }}$ & $\mathrm{F}_{\text {Tab }}$ & Descript. \\
\hline B1 & $\begin{array}{c}9.1 \\
2\end{array}$ & 1.03 & 1.56 & $\begin{array}{c}\text { Homogeneo } \\
\text { us }\end{array}$ \\
\cline { 1 - 2 } B2 & $\begin{array}{c}8.8 \\
0\end{array}$ & & & \\
& & & \\
\hline
\end{tabular}

Table above shows that $\mathrm{F}_{\text {Observed }}=1.03$ from group of high and low learning motivation are lower than $\mathrm{F}_{\text {Table }}=1.56$. thus it can be concluded that the population of each learning motivation group is homogenous.

\section{Groups of Interaction}

The summary on the result of Homogeneity test on groups of interaction shown in Table as follows.

Table Summary on the results of Homogeneity Test on Groups of Interaction

\begin{tabular}{|c|c|c|c|c|c|c|}
\hline Pamples & Df & $\mathbf{1 / d f}$ & $\mathbf{S 1}^{2}$ & $\begin{array}{c}\text { Log } \\
\mathbf{S 1}^{\mathbf{2}}\end{array}$ & DF.S1 $^{\mathbf{2}}$ & $\begin{array}{c}\text { Df.Log } \\
\mathbf{S 1}^{\mathbf{2}}\end{array}$ \\
\hline 1 & 29 & 0.03 & 39.84 & 1.59 & 1155.36 & 46.11 \\
\hline 2 & 29 & 0.03 & 67.1 & 1.82 & 1945.9 & 52.78 \\
\hline 3 & 29 & 0.03 & 29.06 & 1.46 & 824.74 & 42.34 \\
\hline 4 & 29 & 0.03 & 67.5 & 1.82 & 1957.5 & 52.78 \\
\hline Total & 116 & 0.12 & 368.56 & 6.69 & 5883.5 & 194.01 \\
\hline
\end{tabular}


Table The Result of Homogeneity Test

\begin{tabular}{|c|c|c|c|c|c|}
\hline $\begin{array}{c}\text { Log } \\
\mathrm{S}_{2}\end{array}$ & $\mathrm{~B}$ & $\mathrm{Df}$ & $\mathrm{X}^{2}{ }_{\text {Observ. }}$ & $\mathrm{X}_{\text {Table }}^{2}$ & Descript. \\
\hline 1.69 & $\begin{array}{c}196.0 \\
4\end{array}$ & 3 & 4.675 & 7.815 & $\begin{array}{c}\text { Homogenou } \\
\mathrm{s}\end{array}$ \\
\hline
\end{tabular}

Table above presents that the value of $\mathrm{X}^{2}$ Observed is 4.675 and it is lower than $X^{2}$ Table that is 7.815 . So, it can be concluded that the data on the students' achievement scores in writing argumentative have homogenuos variance. Thus the research data had normal distribution and homogenuos variance. Therefore the requirements of the data had been fulfilled and could be continued to the hypotheses by using Two-Way ANOVA.

\section{Hypotheses Testing}

The research hypotheses were tested by using Two-Way ANOVA $2 \times 2$ Factorial design. The data description is presented in Table below.

Table Data Description of Two-Way ANOVA with $2 \times 2$ Factorial Design

\begin{tabular}{|c|c|c|c|}
\hline Learning & \multicolumn{2}{|c|}{ Teaching Technique } & \multirow{2}{*}{ Total } \\
\cline { 2 - 3 } Motivation & CPPT & WWT & \\
\hline \multirow{3}{*}{ High } & $\mathrm{N}=30$ & $\mathrm{~N}=30$ & $\mathrm{~N}=60$ \\
& $\Sigma \mathrm{X}=2684$ & $\Sigma \mathrm{X}=2347$ & $\Sigma \mathrm{X}=5031$ \\
& $\bar{X}=89.46$ & $\bar{X}=78.23$ & $\bar{X}=83.85$ \\
\hline \multirow{3}{*}{ Low } & $\mathrm{N}=30$ & $\mathrm{~N}=30$ & $\mathrm{~N}=60$ \\
& $\Sigma \mathrm{X}=1993$ & $\Sigma \mathrm{X}=2024$ & $\Sigma \mathrm{X}=4017$ \\
& $\bar{X}=66.43$ & $\bar{X}=67.46$ & $\bar{X}=66.95$ \\
\hline \multirow{3}{*}{ Total } & $\mathrm{N}=60$ & $\mathrm{~N}=60$ & $\mathrm{~N}=120$ \\
& $\Sigma \mathrm{X}=4677$ & $\Sigma \mathrm{X}=4371$ & $\Sigma \mathrm{X}=9048$ \\
& $\bar{X}=77.95$ & $\bar{X}=72.85$ & $\bar{X}=75.4$ \\
\hline
\end{tabular}

The complete calculation of Two-Way ANOVA with Factorial Designs can be seen in Appendix K. The summary of the calculation that tested the research hyphotheses is revealed in Table below.
Table Summary of the Calculation Result of Two-way ANOVA

\begin{tabular}{|c|c|c|c|c|c|c|}
\hline $\begin{array}{c}\text { Source of } \\
\text { Variation }\end{array}$ & Df & Ss & Ms & Fobs & $\begin{array}{c}F_{\text {tab }} \\
\alpha=0.05\end{array}$ & Descript \\
\hline $\begin{array}{c}\text { Means of } \\
\text { Treatement }\end{array}$ & 1 & $\begin{array}{c}682219 . \\
2\end{array}$ & $\begin{array}{c}6822 \\
19.2\end{array}$ & & & \\
\hline $\begin{array}{c}\text { Teaching } \\
\text { Techniques }\end{array}$ & 1 & 8568.5 & $\begin{array}{c}8568 \\
.5\end{array}$ & 73.8 & 3.92 & Signif. \\
\hline $\begin{array}{c}\text { Learning } \\
\text { Motivation }\end{array}$ & 1 & 780 & 780 & 6.72 & 3.92 & Signif. \\
\hline Interaction & 1 & 3296.3 & $\begin{array}{c}3296 \\
.3\end{array}$ & 28.4 & 3.92 & Signif. \\
\hline Error & 116 & 3295.7 & $\begin{array}{c}28.4 \\
1\end{array}$ & & & \\
\hline Total & 120 & $\begin{array}{c}698159 . \\
7\end{array}$ & & & & \\
\hline
\end{tabular}

The Statistical hypotheses are:

$$
\begin{aligned}
& \text { Ho: } \mu A_{1}=\mu A_{2} \\
& \text { Нa: } \mu A_{1}>\mu A_{2}
\end{aligned}
$$

The result of the data analysis indicates that the mean score of the students' achievement in argumentative writing taught by CPPT is 77.95 and the mean score of the students' achievement in argumentative writing taught by WWT is 72.85 . Based on the data in Table 4.16 that $\mathrm{F}_{\text {Observed }}=73.8$ and $\mathrm{F}_{\text {Table }}$ is 3.92 , it is indicates that the value of $\mathrm{F}_{\text {Observed }}>\mathrm{F}_{\text {Table }}(73.8>$ 3.92). Thus null Hypothesis (Ho) is rejected at the level significance $=$ 0.05 . Therefore, it can be concluded that the research hypothesis which states that students' argumentative writing achievement taught by CPPT is higher then that taught by WWT is accepted.

The statistical hypotheses are:

$$
\begin{aligned}
& \text { Ho: } \mu B_{1}=\mu B_{2} \\
& \text { Ha: } \mu B_{1}>\mu B_{2}
\end{aligned}
$$

The result of the data analysis indicates that the mean score on 
students' achievement in argumentative writing of high learning motivation students is 83.5 and the average score of low learning motivation students is 66.95. The ANOVA table shows that $\mathrm{F}_{\text {Observed }}$ is 6.72 and $\mathrm{F}_{\text {Table }} 3.92$, so null hypothesis (Ho) was rejected at the level significance $\alpha=0.05$. therefore, the second hypothesis that the students' argumentative writing achievement with high learning motivation is higher than that of low learning motivation is accepted.

The statistical hypotheses are:

$$
\begin{aligned}
& \text { Ho: } A><B=0 \\
& \text { Ha }: A><B \neq 0
\end{aligned}
$$

The results of the data analysis shows that the average $F_{\text {Observed }}$ is 28.4 and $F_{\text {Table }}$ is 3.92. it means that there is an interaction between teaching techniques and learning motivation because $\mathrm{F}_{\text {Observed }}$ $=28.4<\mathrm{F}_{\text {Table }}=3.92$.

The interaction between teaching techniques and learning motivation can be exemined based on pairs of average scores on students' achievement in argumentative writing.

In general, the result of Tuckey-test calculation indicates that the six combination of the comparison of the average students' achievement in argumentative writing based on ANOVA $2 \times 2$ factorial design shows in Table 4.17. The result of Tuckey-test calculation is drawn in the conclusions as follows. a. For $\mu \mathrm{A}_{1} \mu \mathrm{B}_{1}>\mu \mathrm{A}_{2} \mu \mathrm{B}_{1}$ the calculation of the average score on group of high learning motivation students taught by CPPT (89.6) is higher than the average score on group of high learning motivation taught by WWT (78.23). Analysis result indicates that $\mathrm{F}_{\text {Observed }}>\mathrm{F}_{\text {Table }}$ (17.14> 3.92). So, it can be conclude that the achievement in argumentative writing on group of high learning motivation taught by CPPT is higher than the achievement in argumentative writing on group of high learning motivation taught by WWT.

b. For $\mu \mathrm{A}_{1} \mu \mathrm{B}_{1}>\mu \mathrm{A}_{1} \mu \mathrm{B}_{2}$ the calculation result of the average score on group on group of high learning motivation students taught by CPPT (89.6) is higher than the average score on group of low learning motivation taught by CPPT (66.43). Analysis result indicates that $\mathrm{F}_{\text {Observed }}>\mathrm{F}_{\text {Table }}$ (47.97 > 3.92). So, it can be concluded that the achievement in argumentative writing on group of high learning motivation taught by CPPT is higher than of the achievement in argumentative writing on group low learning motivation taught by CPPT.

c. For $\mu \mathrm{A}_{1} \mu \mathrm{B}_{1}>\mu \mathrm{A}_{2} \mu \mathrm{B}_{2}$ the calculation result of the average score on group of high learning motivation taught CPPT (89.46) is higher than the average score on group of low learning motivation taught by WWT (67.46). Analysis result indicates that the value of 
$\mathrm{F}_{\text {Observed }}>\mathrm{F}_{\text {Table }}(45.83>2.89)$.

So, it can be conclude that the achievement in argumentative writing on group of high learning motivation taught by using CPPT is higher than the achievement in argumentative writing on group low learning motivation taught by WWT.

d. For $\mu \mathrm{A}_{2} \mu \mathrm{B}_{1}>\mu \mathrm{A}_{1} \mu \mathrm{B}_{2}$ the calculation result of the average score on group of high learning motivation taught by WWT (78.23) is higher than of the average score on group of low learning motivation taught by CPPT (66.43). Analysis results indicate that the value $\mathrm{F}_{\text {Observed }}>$ $\mathrm{F}_{\text {Table }}(24.58>3.92)$. So, it can be concluded that the achievement in argumentative writing on group of high learning motivation taught by WWT is higher than of the achievement in argumentative writing on group of low learning motivation taught by CPPT.

e. For $\mu \mathrm{A}_{2} \mu \mathrm{B}_{1}>\mu \mathrm{A}_{2} \mu \mathrm{B}_{2}$ the calculation result of the average score on group of high learning motivation taught by WWT (78.23) is higher than the average score on group low learning motivation taught by using WWT (67.46). Analysis results indicate that the value $\mathrm{F}_{\text {Observed }}>\mathrm{F}_{\text {Table }}$ (22.43 >3.92). So, it can be concluded that the achievement in argumentative writing on group of high learning motivation taught by WWT is higher that of the group of low learning motivation taught by WWT. f. For $\mu A_{2} \mu B_{2}>\mu A_{1} \mu B_{2}$ the calculation result of the average score on group of low learning motivation taught by CPPT (67.46) is higher than of the average score on group of low learning motivation taught byWWT (63.43). Analysis results indicate that $\mathrm{F}_{\text {Observed }}>\mathrm{F}_{\text {Table }}(8.39$ $>3.92)$. So, it can be conclude that the achievement in argumentative writing on group of low learning motivation taught by WWT is higher than of the achievement in argumentative writing on group of low learning motivation by CPPT.

The interaction between teaching techniques and learning motivation is shown in Figure as follows.

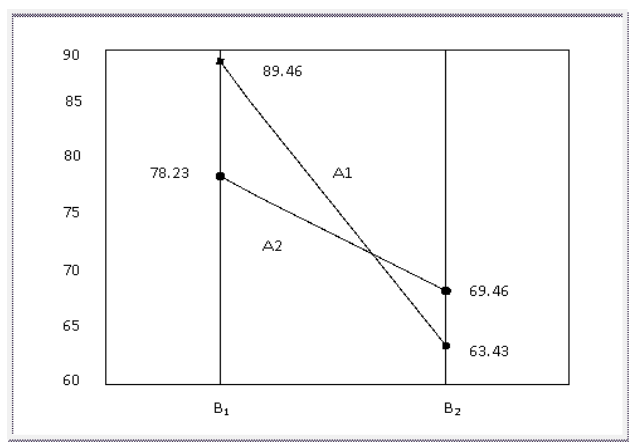

Figure Interaction between Teaching Techniques and Learning Motivation

Figure above displays that the highest score of students with high learning motivation taught by CPPT is 89.46 and the lowest score is 63.43. Thus the highest score of students with high learning motivation taught by WWT is 78.23 and the lowest is 63.46 . 


\section{RESEARCH FINDINGS}

After analysing the data, the problem statements were successfully testified. The findings of the research are:

a. CPPT and WWT significantly affected the students' achievement on argumentative writing. The mean score of students' achievement on argumentative writing taught by using CPPT was higher than of the mean score of students' achievement in argumentative writing taught by using WWT. Thus, the first hypothesis was accepted.

b. Students' learning motivation significantly affect students' achievement in argumentative writing. It was found that the achievement in argumentative writing of the students who have high learning motivation was higher than the achievement in argumentative writing of the students who have low learning motivation. Thus, the second hypothesis was accepted.

c. There is an interaction between teaching techniques and learning motivation to the students achievement in argumentative writing. It means that the third hypothesis of was accepted.

\section{CONCLUSION}

Based on the data analyses and hypotheses testing, it is conclude that: a. The students' achievement on argumentative writing taught by Consultancy Prewriting Protocol Technique (CPPT) was higher than that of taught by Word Wall Technique (WWT).

b. The students' achievement on argumentative writing of the students with high learning motivation was higher than the students with low learning motivation.

c. There was significant interaction between teaching techniques and learning motivation on students' achievement in argumentative writing . Students' achievement in argumentative writing was influenced by teaching techniques and learning motivation. High learning motivation students who taught by CPPT got higher achievement on argumentative writing. While Low learning motivation students who taught by WWT got higher achievement on argumentative writing

\section{REFERENCES}

Ausubel, M. 2000. Students' Motivation. New York: Routledge.

Bachman, L.F. and Palmer, A.S. 1991. Language Teaching in Practice. New York: Oxford University Press.

Badger, R. and White, G. 2000. 'A Process Genre Approach to Teaching Writing.' ELT Journal, 54/2: 153-160. 
Brown, D. H. 2004. Language Assessment: Principle and Classroom Practices. New York: Pearson Education.

Clark, I. L. 2003 Theory and Practice in the Teaching of Writing. New Jersey: Lawrence Erlbaum Associates, Publishers.

Cunningham, P. M. 1995.Words for Reading and Writing. New York: Harper Collins Publishers.

Elce, M, M. 2001. Teaching English as a Second or Foreign Language (3rd edition), Boston: Heinle and Heinle.

Elbow, P. 2000. Everyone can Write: Essays Toward a Hopeful Theory of Writing and Teaching Writing. New York: Oxford University Press.

Gebhard, J. 2000. Teaching English as a Foreign or Second Language: A Teacher Selfdevelopment and Methodology Guide. Michigan: The University of Michigan Press.

Graham, S., M, C.A., and Fitzgerald, J. 2007. Best Practices in Writing Instruction. New York: The Guilford Press.

Knap, P and Watkins, M. 2005. Genre, Text Grammar. Sidney: University of New South Wales.

Linse, C.T. 2005. Practical English language Teaching: Young Learner. New York: McgrawHill.

Lippan, N, J. 2003. “Assessing Writing (pg. 199-240)" in
Concepts in Compositions: Theory and Practice in Teaching of Writing. New Jersey: Lawrence Erlbaum Associates, Publishers.

Mc. Andrews, S. L. 2008. Diagnostic Literacy Assessment Strategies. International Reading Association.

Murcia, M.C. 2001. Teaching English as a Second or Foreign Language 3th Edition. The United States of America. Thomson Learning.

Pusat Kurikulum. 2006. Kurikulum Tingkat Satuan Pendidikan (KTSP) Bahasa Inggris untuk Sekolah Menengah Kejuruan (SMK). DEPDIKNAS. Jakarta.

Scherer, M. 2009. Engaging the Whole Child: Reflections on Best Practices in Learning, Teaching, and Leadership. Beauregard St. Alexandria, VA USA.

Sevilla, Consuelo G. et. Al. 2007. Research Methods. Rex Printing Company. Quezon City.

Sokolik, M . 2003. Writing. Practical English Language Teaching. New York, NY: McGraw-Hill, 87-107. 
